\title{
The Effectiveness of Plea and Sentence Agreements in Environmental Enforcement in South Africa
}

T Murombo* and I Munyuki**

\section{P.E.R}

Pioneer in peer-reviewed, open access online law publications

Authors

Tumai Murombo

Isaac Munyuki

Affiliation

University of the Witwatersrand TGR Attorneys Inc. Johannesburg South Africa

Email

tmurombo@gmail.com munyukiisaac@gmail.com

Date Submission

29 May 2019

Date Revised

17 July 2019

Date Accepted

17 July 2019

Date published

25 October 2019

Editor Prof A Agbor

How to cite this article

Murombo T and Munyuki I "The

Effectiveness of Plea and Sentence

Agreements in Environmental

Enforcement in South Africa" PER /

PELJ 2019(22) - DOI

http://dx.doi.org/10.17159/1727-

3781/2019/v22i0a5685

Copyright

http://dx.doi.org/10.17159/1727- 3781/2019/v22i0a5685

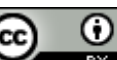

\section{DOI}

\begin{abstract}
A recent development in South African environmental law is the use of plea and sentencing agreements. The main objective of environmental law is to promote the sustainable use of natural resources while preventing pollution and ecological degradation. Grand environmental due diligence processes could achieve sustainable development; the use of criminal sanctions with sentencing agreements could be more effective. This paper answers the question whether the plea and sentencing agreements in reality achieve the objectives of environmental regulation? This study analyses this recent development by looking at selected recent cases in South Africa. The study found that plea and sentence agreements are potentially effective, subject to the effective monitoring of compliance and enforcement against non-compliance with the undertakings made by the accused person. Without institutional strengthening and effective monitoring, the plea and sentence agreement procedure remains ineffective.
\end{abstract}

\section{Keywords}

Environmental law; compliance and enforcement; plea and sentence agreements; criminal sanctions; South Africa. 


\section{Introduction: Legal context of criminal environmental enforcement}

A fundamental challenge for environmental law globally and in South Africa is the inability to design, develop and implement effective enforcement tools. Generally, many countries have modernised their environmental legislation to include framework environmental legislation, which provides the broader structure, key principles and norms, and the institutional architecture for environmental regulation. ${ }^{1}$ Similarly, many countries have developed good sectoral environmental laws such as legislation on water, air pollution control, waste, hazardous substances control, marine resources and marine pollution, environmental planning and environmental impact assessment. ${ }^{2}$

A typical feature of the enforcement provisions in most environmental legislation is the persistence of criminal penalties or sanctions as a method of punishing environmental offenders. Invariably, for example, all of South African environmental legislation uses criminal penalties to enforce its prescriptions. The standard "offences" clause is an ingrained element of most environmental statutes. The use of "offences" per se shows that criminal penalties remain the preferred enforcement mechanism, ${ }^{3}$ while other enforcement mechanisms such as economic instruments and civil

Tumai Murombo. LLB (Hons) (Uni Zim) LLM (UCT) LLM (Pace) PhD (Wits). Professor, School of Law, University of the Witwatersrand, Johannesburg, South Africa. Email: tmurombo@gmail.com. A conceptual working draft of this paper was presented at the 14th Annual Colloquium of the IUCN Academy of Environmental Law in Oslo, Norway on, 23 June 2016. This research was supported by the National Research Foundation of South Africa (Grant No 1091780). The research assistance provided by Amandla Mkongwana in 2017 is acknowledged.

* Isaac Munyuki. LLB (cum laude) LLM (Wits). Senior Associate, TGR Attorneys Inc. Johannesburg, South Africa. Email: munyukiisaac@gmail.com.

$1 \quad$ Faure and Du Plessis "Comparative and Concluding Remarks" 596: "Many African countries have also moved to some sort of codification of environmental law in the sense that they provide for an environmental framework law. This is the case, for example, in Cameroon, Ethiopia, Malawi, Namibia, Nigeria, South Africa, Swaziland, Tanzania, Kenya, Zimbabwe, Mozambique and Uganda."

2 Many countries now have environmental management statutes focussed on specific aspects or components of the environment.

3 Patterson "Incentive-based Measures" 306 ("... with criminal law being the primary tool for ensuring compliance and enforcement, the noted deficiencies of the criminal process are relevant"); also see Holder and Lee Environmental Protection, Law and Policy 382 (commenting that "Enforcement of environmental law in the UK relies heavily on the existence of criminal law but criminal law is rarely the first resort of regulators; negotiation is usually the starting point, and administrative, rather than criminal sanctions have real attractions".) 
remedies are by default regarded as the alternatives. ${ }^{4}$ The predominance of criminal penalty provisions overshadows the few clauses on alternative enforcement methods such as administrative measures and market-based incentives. The suitability of some market-based instruments for Africa has been questioned, however.

Despite its continued use, criminal law as part of the chief command and control tool, has proved limited in its ability to achieve its inherent aims of the deterrence and punishment of environmental offenders. ${ }^{5}$ Concomitantly, criminal law has also struggled to achieve the aims of environmental law, namely to clean up contamination or rehabilitate degraded environments. ${ }^{6}$ While preferred, criminal law is bedevilled by several weakness. A detailed study of the strength and weakness of criminal environmental enforcement has been exhaustively done. ${ }^{7}$ Generally the weaknesses include the huge costs, the reactive nature of criminal law, ${ }^{8}$ the low conviction rates, the low fines, ${ }^{9}$ poor crime detection and investigation skills, and the lack of expertise among the prosecutors and the judiciary. ${ }^{10}$ These weaknesses can be more

$4 \quad$ The tendency to rely on criminal enforcement is empirically demonstrated by the National Environmental Compliance and Enforcement Report 2013/14 compiled by the Environmental Management Inspectorate (EMI). The report records "Arrests" of 1339 (in 2011), 1818 (in 2012), and 1371 in 2013 (DEA EMI 2014 2013/14https://www.environment.gov.za/otherdocuments/reports\#compliance2013 _14). Contrast this with "Directives issued" for the same years, being 49, 36 and 60, and the number of "Civil court applications", namely 7, 4 and 2. The picture remains the same in the 2016/17 Environmental Compliance and Enforcement Report 13 with recorded "Arrests" being 1259 (2014), 939 (2015) and 1092 (2016/17), while the number of cases where an alternative enforcement measure was adopted are all below 200 (DEA EMI 2017 https://cer.org.za/wpcontent/uploads/2016/08/NECER-2016-17.pdf). Demonstrably, alternative enforcement measures are underutilised and there is a preference for criminal arrests and prosecution.

5 Du Plessis and Nel "Driving Compliance to and Enforcement of South African Legislation" 262; also see Kidd "Criminal Measures" 242-243 (detailing the inherent and contingent weakness of criminal sanctions).

6 Of the six cases of plea and sentence agreements discussed in this article, only in one case ( $S$ v Acker (Hermanus Regional Court) (unreported) case number ECH 100/05 (October 2005) ( $S \vee$ Acker)) were researchers able to get a meaningful progress report which indicated that the prosecutors had enforced the undertakings therein. On the other five cases there was either no response or just promises of progress reports which never materialised to the date of publication.

$7 \quad$ Kidd "Criminal Measures".

$8 \quad$ Patterson "Incentive-based Measures" 307 ("it is generally reactive as opposed to proactive and, accordingly, an inappropriate tool for preventing environmental degradation").

$9 \quad$ Holder and Lee Environmental Protection, Law and Policy 395 (lamenting the ineffectiveness of criminal fines against well-resourced corporations).

10 Glazewski Environmental Law ch 26-17; also see Mueller "Essay on Environmental Criminality" 7; Kidd "Criminal Measures" 265. 
pronounced when dealing with corporate offenders, who are increasing the major violators of environmental laws.

The manifestation and prominence of these weaknesses vary from one jurisdiction to another ${ }^{11}$ with a number of developed countries now having relatively improved the efficacy of criminal environmental enforcement. There is now a huge body of literature on these varied jurisdictional experiences with criminal enforcement of environmental law. ${ }^{12}$ This is often achieved through, among other means, the establishment of environmental courts or tribunals, ${ }^{13}$ the provision of specialist training to crime investigators, prosecutors and the judiciary on environmental offences, and stiffer penalties coupled with strict liability. ${ }^{14}$ Specialised courts have proliferated across the world, with different impacts on environmental enforcement and public interest environmental litigation. ${ }^{15}$

In South Africa the weaknesses of criminal environmental enforcement largely remains an issue, and beyond an experimental attempt with marine resources, South Africa does not as yet have specialised environmental courts. ${ }^{16}$ This is so, given the general weakness of South Africa's criminal justice system, which is plagued by delays, inefficiencies including the poor management of evidence, low conviction rates, and a general inability to deal with the influx of criminal cases coming through the system. ${ }^{17}$ In this

11 Kidd "Criminal Measures" 242 notes that these weaknesses are found in most criminal law systems.

12 Billiet, Blondiau and Rousseau 2014 Regul Gov; Strock 1990 Geo Wash L Rev 916; also see generally Faure et al. Criminal Enforcement of Environmental Law for an extensive regional survey of selected European Union member states; White Crimes against Nature (exploring in extensive detail the criminology of environmental harm, its philosophical foundations, and the legal nature of criminal environmental enforcement.); White 2012 Australasian Policing 7-11 (discussing the role of civil society organisations in enabling criminal enforcement of environmental law); also see Wellsmith 2011 Eur J Crim Policy Res 125-148; Ruggiero and South 2013 Crit Criminol.

13 Extensive literature now exits on the growth of environmental courts and tribunals worldwide. For comprehensive surveys and studies see generally, Pring and Pring Greening Justice; Pring and Pring 2009 Or Rev Int'l L 301-329; Preston 2014 JEL 365-393; Robinson 2012 Pace Envtl L Rev 363-395. (These studies analyse the factors contributing to the success of environmental courts as well as other implications of environmental courts for environmental rights, access to justice and environmental enforcement.)

$14 \quad$ Wang 2016 FJHSS 607.

15 Pring and Pring Greening Justice; Pring and Pring 2009 Or Rev Int'l L 301-329; Preston 2014 JEL 365-393; Robinson 2012 Pace Envtl L Rev 363-395.

16 Kings 2017 https://mg.co.za/article/2017-05-09-environmentalists-are-winning-thebattle-for-enforcement-of-the-law; also see generally Hauck and Kroece 2006 Marine Policy. 
paper we undertake an evaluation of recent developments in South African criminal environmental enforcement. Having highlighted the documented weakness of criminal sanctions, we hasten to caution that alternative enforcement mechanisms are not by themselves efficacious. Thus, pertinently, Faure concludes that:

As long as command and control approaches are designed with at least one eye on cost saving, incentive-based systems are not necessarily superior. One therefore has to be careful not to distinguish the two systems too sharply. ${ }^{18}$

Eventually, any mechanism may require enforcement, which ultimately could end with criminal sanction. A fortiori, the plea and sentencing agreement, the subject of this study, is designed within the criminal law system.

There is an upsurge in the use by prosecutors and a judicial affinity towards what is generally called plea-bargaining leading to plea and sentence agreements. This is not to say that plea-bargaining is a recent legal development as such, ${ }^{19}$ but rather that the use of that procedure in environmental prosecutions coupled with innovative court orders (environmental service orders, compensation awards and research funding) is unique in environmental criminal enforcement. This innovation has the potential to provide possibilities to make environmental criminal enforcement effective, and other countries could draw lessons from the South African experiment. This approach has also been adopted in other countries such as the USA and Australia. ${ }^{20}$

The research for this paper took two forms. Firstly, we performed a critical desktop analysis of the law and cases. Secondly, we used an empirical methodology partly to obtain feedback from expert administrators on the progress made in implementing plea and sentence cases. A concise sample of most relevant cases was selected for analysis. We augmented this with empirical follow-up surveys that were conducted with expert law enforcement and regulatory agencies involved in each case. The survey sought to elicit progress reports on the implementation of the plea agreements and the payment of agreed compensation. We summarised the

\footnotetext{
18 Faure "Balancing of Interests" 24.

19 See for example Bekker 1996 CILSA 168-222 (comparative analysis of plea agreements in the USA and South Africa in general and whether the USA principles were relevant to South Africa, which then did not have a legal framework for sentence bargaining). 
cases for relevance and distributed a questionnaire ${ }^{21}$ which asked prosecutors, magistrates or relevant government departments to provide feedback. While the study itself did not involve human subjects, ethical clearance was obtained to ensure that the administration of the electronic questionnaire complied with the requirements of ethical research. ${ }^{22}$

This approach was adopted to complement and provide some practical information to augment the theoretical critical analysis of the plea and sentencing legal framework and how it has been used by the courts so far in South Africa. Through the theoretical and empirical review of some recent cases, ${ }^{23}$ we argue that the increasing use of plea and sentence agreements in South Africa may carry better prospects for achieving the real objectives of environmental regulation.

The remedial orders and compensation awards ${ }^{24}$ strengthen the potential to align criminal law with the aims and outcomes of environmental regulation. It represents a departure from the orthodox use of criminal law, where the focus was largely on the prospect of deterring would-be offenders by heavily punishing the accused $^{25}$ while the environment remained degraded. ${ }^{26}$ South Africa's experience can provide useful insights to other countries that wish to innovatively make criminal environmental enforcement more effective through consensus-based enforcement. This includes joint and transnational enforcement, especially in matters involving

21 After a concise summary of each case and its outcome, the questionnaire, sent by email, contained the following questions: "We,... seek the following feedback: (a) state if the above sentence was complied with; (b) if the accused submitted compliance/rehabilitation reports (we kindly request copies of same if available) (c) and if there was no compliance, what were the consequences of not complying with the agreement. We would kindly appreciate it also if we are made aware of the consequences that followed in the case of non-compliance with the plea sentence conditions."

22 Ethics Clearance Protocol Number: H19/06/24.

23 This is not an exhaustive review of all the cases, since Magistrates courts, whose judgments are not reported, hear most of these cases. There are probably more cases that have not been picked up.

$24 \quad$ Mandated both in terms s 34 of the National Environmental Management Act 107 of 1998 (NEMA) and ss 297 and 300 of the Criminal Procedure Act 51 of 1977.

$25 \quad$ Holder and Lee Environmental Protection, Law and Policy 393.

26 In addition, any criminal fines paid by offenders would go to the government central revenue fund without being ring-fenced to support environmental regulation and enforcement efforts. South Africa and the USA have recently collaborated in one of the biggest cases to recover compensation from abalone poachers; see US $v$ Bengis No $13-2543$ (2d Cir 2015) (where the accused were ordered to pay US61 million, later reduced to US\$22 million, although the South government believes this amount should have been US $\$ 100$ million; Bengis $v$ Government of South Africa; In re: Bengis $v$ Government of South Africa 20162 All SA 459 (WCC); also see Glazewski 2014 IJMCL 173-183. 
international environmental crimes, as illustrated by the recent case of US $v$ Bengis, ${ }^{27}$ for example. This approach could also be relevant to enforcement against environmental violations by transnational corporations. $^{28}$

We first highlight the fundamental objectives of environmental regulation, then we provide an overview of the general legislative framework for plea and sentencing agreements in South Africa. In the context of the general context provided in the first and second parts, the third part of the paper evaluates the application of plea and sentencing procedure in environmental enforcement, through selected illustrative cases. We conclude the paper by analysing the extent to which the use of plea and sentence agreements can result in better outcomes for the environment, noting possible challenges to the procedure in South Africa. We also highlight areas for further research in this evolving area of environmental law.

\section{Objectives of environmental enforcement}

Environmentalists, whether in academic circles, civil society or government, often project the idea that the fundamental aim of environmental law is to promote environmental or ecological integrity. ${ }^{29}$ To the extent that environmental laws in fact enable any use of natural resources and some pollution, it is contestable whether it aims to achieve "ecological integrity" as such. Nevertheless, the human aspiration towards ecological integrity is undergirded by a desire to sustainably use natural resources with minimal environmental damage.

In South Africa the objectives of environmental regulation are aptly captured in section 24 of the Constitution, which provides for the right to an

US v Bengis No 13-2543 (2d Cir 2015) in which a US court under the Lacey Act, 1900 handed a heavy sentence to rock lobster poachers who had smuggled their catch into the US. The Act provides that, "It is unlawful for any person... (2) to import, export, transport, sell, receive, acquire, or purchase in interstate or foreign commerce- $(A)$ any fish or wildlife taken, possessed, transported, or sold in violation of any law or regulation of any State or in violation of any foreign law". 16 USC $\S$ 3372(a)(2)(A).

$28 \quad$ White 2005 Curr Issues Crim Justice 276.

29 Environmental or ecological integrity is not what many popularly want it to be. Pimentel, Westra and Noss "Ecological Integrity" 20 notes that "integrity" implies imagery wholeness, perfect and unimpaired; Bridgewater, Kim and Bosselman 2014 $Y b$ Int'l Env $L 64$ maintain that there is no consensus on what precisely "ecological integrity" means. 
environment not harmful to health and well-being. ${ }^{30}$ The Constitution further imposes positive obligations on the state, through reasonable legislative or other measures, to prevent pollution and promote conservation, whilst ensuring that ecologically sustainable development can take place. ${ }^{31}$ These objectives of environmental regulation are not necessarily the core concern of criminal law, which serves a much broader purpose. ${ }^{32}$

The framework environmental legislation, the National Environmental Management Act, ${ }^{33}$ also attests to the fundamental aims of environmental law. Other environmental legislation on water, air, biodiversity, and protected areas all equally reaffirm the constitutional focus on the sustainable use of natural resources and ecological integrity. Similarly, the Minerals and Petroleum Resources Development Act ${ }^{34}$ also espouses the principle of the sustainable use of mineral resources. Among several tools and strategies used in environmental law to achieve these regulatory objectives, we find land use plans, quality-based and technology-based pollution control tools and standards, together with the criminalisation of most violations of the environmental and natural resources legislation.

Therefore, in an ideal world, given the aims of environmental law, the tools and measures used in legislation should proactively aim to pre-empt actions or conduct that has the potential to damage the environment, cause pollution or lead to the unsustainable use of natural resources. Debate continues on the relative merits of measures taken before harm (act-based) has occurred and those taken after harm (harm-based) has occurred to the environment. ${ }^{35}$ Permitting, licensing and planning tools would seem better suited to the objectives of environmental regulations than ex post facto enforcement measures. ${ }^{36}$ Discussing this intricate controversy, Rousseau

30 Section 24(a) of the Constitution of the Republic of South Africa, 1996 (the Constitution).

31 Section 24(b) of the Constitution. The notion of ecological sustainability is more realistic than that of maintaining "ecological integrity".

32 Holder and Lee Environmental Protection, Law and Policy 393.

33 National Environmental Management Act 107 of 1998 (hereafter the NEMA).

$34 \quad$ Minerals and Petroleum Resources Development Act 28 of 2002 (hereafter the MPRDA). Among other objects, $s$ 2(h) provides that the MPRDA was enacted to "give effect to $s 24$ of the Constitution by ensuring that the nation's mineral and petroleum resources are developed in an orderly and ecologically sustainable manner while promoting justifiable social and economic development". See Rousseau and Blondiau 2014 Environ Policy Gov 440 discussing the relative advantages of acts-based (before environmental damage) against harm-based (after damage is caused) environmental criminal sanctions. 
and Blondiau argue that:

Both types of sanction have their strengths and weaknesses... The main strength of act-based sanctions is that they intervene at an early stage, i.e. before the harm is done. However, such an enforcement strategy can rapidly inflate the number of punishments imposed and thus the costs associated with prosecution and sanctioning. Moreover, act-based sanctions lead to overinclusion, since some of the individuals who are punished would not have caused environmental harm and thus punishing them does not protect the environment as such. This aspect of overinclusion can be problematic for scholars or policy makers who allow for punishment of conduct only when it gives rise to personal gains. However, from the point of view of deterrence, overinclusion is acceptable as long as it leads to a net reduction of harm and protects the environment. ${ }^{37}$

However, the question that arises is what regulators and enforcement agencies should do with persons who - despite having permits, licences or authorisations - violate the terms and conditions of such permits and those who blatantly undertake environmentally regulated activities without complying with the prescripts of the law? Even if such acts do not result in significant harm to the environment. This is where act-based criminalisation becomes indispensable as the tried and tested tool to bring offenders to account. It is at this level that the unique objectives of environmental law give way to broader societal imperatives of arresting criminality.

Another unanswered question is whether framing this as a criminal law issue is itself not a flawed foundation for the discourse? It could be argued that criminal law was not conceived to deal with the type of crimes that environmental crimes are. After all, many environmental offenders perceive their acts to be less reprehensible than heinous and egregious crimes like murder, robbery and rape. ${ }^{38}$ This psychology of the benign environmental "criminal" remains a constraint on the criminal enforcement of environmental law. ${ }^{39}$ Martín et al. rightly observe that "[e]nvironmental crimes harm both the environment and human beings but are not universally perceived as illegal, or even reproachable". ${ }^{40}$ Unless it is a reprehensible

$37 \quad$ Rousseau and Blondiau 2014 Environ Policy Gov 440 (footnotes omitted)

38 White 2017 Crime Law Soc Change 117 stating that "Environmental harms are frequently built into ordinary commercial practice and the everyday routines of people. The law both facilitates and reinforces the legitimacy of this, for example, by granting licenses to factories to pollute air and water, albeit within certain limits".

Even the courts have at some point distinguished between the heinous crimes such as murder and robbery on the one hand, and what they call regulatory offences on the other hand, see $S$ v Coetzee 19971 SACR 379 (CC) para 42, traversing USA and Canadian jurisprudence the court emphasised that "The distinction between the 'truly criminal' and 'regulatory' offences has been discussed in various judgments in a number of jurisdictions". Martín et al. 2013 Soc Justice Res 321. 
pandemic such as hacking horns off a rhino or a big oil spill, many people, and indeed criminal justice systems, remain oblivious to conduct that threatens, damages or pollutes the environment. ${ }^{41} \mathrm{~A}$ perennial issue within green criminology, for instance, is the perception that the formal institutions of criminal justice do not take environmental crime seriously enough. There is plenty of evidence to substantiate this claim.

\section{Plea and sentence agreements in general}

Criminal procedure in South Africa revolves around the architecture of the criminal code, which is the Criminal Procedure Act. ${ }^{42}$ This Act regulates pretrial, trial, and post-trial procedures in detail. Plea-bargaining ${ }^{43}$ had been happening under section 112(2) and (3) of the Criminal Procedure Act without the more detailed specific statutory guidelines introduced by the section 105A amendment. ${ }^{44}$ For the purposes of this paper, our focus is on the pre-trial procedure ${ }^{45}$ in the Criminal Procedure Act. Section 105A was introduced by an Amendment in 2001 to provide a formalised procedure for plea and sentence agreement negotiation and endorsement by the court. ${ }^{46}$ This procedure applies to pending criminal cases in which the prosecutor or the accused, through her attorney, opts to negotiate the plea and a possible sentence. Certain legal requirements have to be fulfilled in order for parties to pursue this procedure.

In detail, section $105 \mathrm{~A}^{47}$ provides that upon authorisation by the National Director of Public Prosecutions, the prosecutor and a legally represented accused may, before the commencement of the trial, negotiate and enter into an agreement regarding a guilty plea by the accused, a possible just

$41 \quad$ Mueller "Essay on Environmental Criminality" 8; White 2017 Crime Law Soc Change 118.

42 Criminal Procedure Act 51 of 1977 as amended (the Criminal Procedure Act).

43 Defined by Kruger Hiemstra's Criminal Procedure 15-5, as follows" "Plea bargaining can be defined as the procedure whereby the accused relinquishes the right to go to trial in exchange for a reduction in sentence; the prosecutor bargains away the possibility of a conviction in exchange for a punishment, which would be retributively just and cost the least in terms of the allocation of resources. In the process of bargaining, numerous assumptions are made. Provided a party is found to have acted freely and voluntarily, in sound and sober senses and without undue influence, the fact that the assumptions turn out to be false does not entitle such a party to resile from the agreement."

$44 \quad$ North Western Dense Concrete CC v DPP, Western Cape 20002 SA 78 (C) (hereafter North Western Dense Concrete).

45 Provided for in ss $105 \mathrm{~A}$ and 112 of the Criminal Procedure Act. S 112 deals with the procedure where a plea of guilty is entered by the accused person.

46 Bekker 1996 CILSA 217-218 (showing the non-existence of sentence guidelines or sentence bargaining in South Africa in 1996).

47 Section 105 of the Criminal Procedure Act provides for plea procedure. 
sentence, or the postponing of sentencing subject to agreed conditions and any award of compensation. ${ }^{48}$

The validity of the agreement between the prosecutor and accused is premised on certain principles of natural justice, administrative due process and meaningful consultation. Given the gravity of the consequences flowing from an accused abnegating the entitlement to defend herself and to have the state prove its case, it is critical that the accused be legally represented. ${ }^{49}$ The prosecutor, who must be authorised to engage in this procedure, must also inform the accused of her right to remain silent, and the presumption of innocence. The accused must also be advised that the plea and sentence agreement does not fetter the direction of the court to call for and hear evidence, should it deem it necessary. It is important for the prosecutor to ensure that the accused is acting as a free agent - freely and voluntarily - without any influence. This includes that the accused is under no obligation to engage in the negotiation process at all, and that once the agreement is sealed the court can still reject it. ${ }^{50}$

Apart from the duty to ensure that the accused is fully briefed and informed of his/her rights, the prosecutor is required to consult certain parties before the agreement becomes valid. The prosecutor must consult with the investigating officer ${ }^{51}$ on the accused's profile, the circumstances of the offence, any previous convictions and the best interests of the community. ${ }^{52}$ Lastly, the prosecutor must consult with the complainant (which in most environmental cases will be the environmental department or the affected community) and allow them to make representations regarding the proposed agreement and any proposed award of compensation or benefit/service order.

However, the Act does not define "complainant", which implies that any person who has suffered harm or damage as a result of the environmental offence has a right to be consulted. ${ }^{53}$ This is critical in environmental

48 Section $105 \mathrm{~A}(1)$ of the Criminal Procedure Act read with s 300, which empowers a Court convicting a person of a criminal offence to award compensation up to set amounts where the offence caused damage to or loss of property. Similarly, s 34B of the NEMA, South Africa's framework environmental statute, empowers a court which convicts an environmental offender to award a percentage not exceeding a quarter of any fine imposed to the person whose evidence led to the arrest and/or conviction of the accused.

49 Section $105 \mathrm{~A}(1)$ (a) of the Criminal Procedure Act.

50 Sections $105 \mathrm{~A}(2)(\mathrm{a})(\mathrm{i})$-(iii)) of the Criminal Procedure Act.

51 Sections $105 \mathrm{~A}(1)(\mathrm{b})(\mathrm{i})$ and $105 \mathrm{~A}(1)(\mathrm{c})(\mathrm{i})$ of the Criminal Procedure Act.

52 Section $105 \mathrm{~A}(1)(\mathrm{b})(\mathrm{ii})$ of the Criminal Procedure Act.

53 Section 105A(1)(b)(iii) of the Criminal Procedure Act. 
offences where it is often civil society and community environmental groups that should be consulted.

When all the requirements are met, the parties must reduce the agreement into writing, sign it, and provide supporting documents for any consents or authorisations required. ${ }^{54}$ Section 105A(3) expressly prohibits the court from participating in the negotiation stage of the plea and sentence agreement.

The court gets involved in the process at the accused's first appearance before it to face the charges. Once the accused is in the dock, the prosecutor announces to the court that an agreement has been negotiated and entered into, whereupon the court considers the circumstances in which the agreement was concluded as well as the terms of the agreement. Instead of merely rubber-stamping the agreement, a court must satisfy itself that the provisions of the Criminal Procedure Act have been fully complied with. The court must also satisfy itself that the accused was informed of his rights and that all required consultations have been done. ${ }^{55}$

Thereafter the court can either ask the accused to actually plead in court and have the contents of the agreement read in court, ${ }^{56}$ or, if the court is not satisfied that the statutory requirements have been met, it can notify the prosecutor and the accused, providing reasons for its dissatisfaction and giving the parties an opportunity to rectify the non-compliance. ${ }^{57}$

Where the court is satisfied that the technical statutory requirements are met, it proceeds to question the accused to confirm that the accused understands the charge, the facts of the crime, and that she acted freely and voluntarily, being of a sober mind, in concluding the agreement with the prosecution. This is to ensure that the accused has not pleaded guilty to a charge that she does not understand, or facts that do not disclose the offence charged. Given the requirement of legal representation, one would assume that the legal practitioner would have apprised the accused of these issues. Once satisfied that the accused understands the nature and implications of the agreement, the court hears submissions in aggravation and mitigation and the minimum statutory sentence, if any, applicable to the offence. Having confirmed the above, and being satisfied that the agreed

\footnotetext{
54 Section 105A(2) of the Criminal Procedure Act.

55 Sections $105 \mathrm{~A}(4)$ (i) and (ii) of the Criminal Procedure Act.

56 Kruger Hiemstra's Criminal Procedure 5-6 citing $S$ v Solomons 20052 SACR 432

(C) 435D-F; see s 105A(5) of the Criminal Procedure Act.

57

Section $105 \mathrm{~A}(4)(\mathrm{b})$ of the Criminal Procedure Act.
} 
sentence is just, the court informs the parties, convicts the accused, and formally imposes the agreed sentence.

It could happen that the court is satisfied with the guilty plea and the conviction of the accused, but not with the sentence agreed by the parties. In that event the court shall inform the parties of its view and advise the parties of what it considers a just sentence. ${ }^{58}$ The prosecution and the accused may accept the court's views, whereupon the case proceeds through the normal sentencing process. In this case the plea agreement stands, but the sentencing is left to the court to decide. The prosecutor and the accused may withdraw from the agreement, upon which it becomes null and void and the matter proceeds to trial de novo. ${ }^{59}$ If the latter happens, the agreement shall not be presented as evidence at the trial unless the accused consents to any admissions made being used in the trial. Clearly, the court does not abdicate its mandate to ensure that any sentence is commensurate with the degree of guilt and seriousness of the offence.

The legislative provisions appear to be designed around the concept of the criminal accused as an individual, which begs the question of how effective this can be against corporate offenders, who are increasingly the major culprits in environmental crimes.

\subsection{The purpose of the plea and sentence procedures}

The purpose behind the elaborate procedure explained above is, perchance, to give the accused hope that by admitting to the crime and saving the court time and cost, she can get away with a lighter or noncustodial sentence. Plea-bargaining is aimed at expediting the criminal process and serving the interests of both the state and the accused person, including "discounting the risk of acquittal" if the matter proceeded to trial. ${ }^{60}$ In North Western Dense Concrete CC the court went to great lengths to articulate the merits and disadvantages of allowing the plea bargaining

$58 \quad$ Kruger Hiemstra's Criminal Procedure 15-7 citing $S$ v Esterhuizen 2005 (1) SACR $490 \mathrm{~T} 494 \mathrm{H}-\mathrm{I}$, where the court correctly cautions that "The fact that a lesser sentence has been agreed upon than that which would conceivably have been imposed at the end of a trail does not mean that justice has not been served."

59 Sections $105 \mathrm{~A}(6)(c)$ and (9)(b) of the Criminal Procedure Act.

60 Kruger Hiemstra's Criminal Procedure 15-5. Also see The National Environmental Compliance and Enforcement Report 2009-10 (DEA EMI 2010 https://www.environment.gov.za/sites/default/files/docs/necer2009_10report.pdf 1) worryingly reporting that "There has been a dramatic increase in the number of acquittals from 18 in 2008/9 to 1026 2009/10". The rate of acquittals supports the argument that the plea and sentence agreement procedure could better serve the interests of the environment than the foolhardy pursuit of criminal prosecution. 
process. It noted that while some attorneys and judges are averse to the process, ${ }^{61}$ it serves a good purpose.

The court noted that, while academics had engaged with the plea agreement procedure, the response by the courts had been rather muted. ${ }^{62}$ The court expressed concern that:

\begin{abstract}
[i]ndeed, the fact that it has received so little attention may indicate that it is neither a recognized nor a recognizable form of procedure. However, on consideration of the matter, the real reason why so little judicial attention has been given to this aspect of criminal procedure becomes apparent. From studies which have been carried out by eminent academics and no less august a body than the South African Law Commission, it appears as if some lawyers and judicial officers are uneasy about the "legality" of plea bargaining. They appear to shy away from recognizing that such a procedure exists. They not only avoid affording it recognition. They refuse to be associated in any way with such a procedure. They regard it with disfavour. ${ }^{63}$
\end{abstract}

However, the academic writing on the plea bargaining process has to date not addressed the use of the process in the modern approach, which includes the making of compensation awards and environmental remediation orders.

It is in this respect that our paper will stimulate further research and debate on whether this development promises a better use of criminal procedure in environmental enforcement. In North Western Dense Concrete CC the court also considered the merits of codifying the procedure and observed obiter that formalising the process would not necessarily make a difference. ${ }^{64}$ However, we argue that it was important to formalise the procedure to ensure that prosecutors, accused persons and complainants have clear guidance and criteria for resorting to plea and sentencing agreement to serve the interests of justice and the accused.

Another interest served by allowing the plea and sentencing agreement process is that it promotes the public interest in ensuring that matters that can quickly be resolved through consensus are so settled, while the court's resources are released to deal with contentious matters that merit a trial. This can decongest the criminal justice system while concomitantly encouraging quick remediation of the damaged environment. Generally, the process can also achieve better results for the complainants in the cases,

$61 \quad$ North Western Dense Concrete 83A-B.

62 North Western Dense Concrete 83B-D (citing Isakow and Van Zyl Smit 1985 De Rebus 17; Isakow, Van Zyl Smit and Isakow 1986 SAJCC 3-20; Clarke 1999 CILSA 141-168).

$63 \quad$ North Western Dense Concrete 82H-83A (footnotes omitted).

64 North Western Dense Concrete 86H-J. 
as there is a possibility of remedying the loss suffered through restitution orders. ${ }^{65}$

In Jansen the court dealt with a pyramid scheme created by the accused to defraud many investors of their investments. A plea and sentence agreement was used to achieve an outcome that was better than sending Jansen to jail. The agreed sentence included repayment to the investors of their capital investments. As Abbot argues, "a fundamental principle in the sentencing of criminal defendants is that the offender should not profit from committing an offence and that the fine should aim at recovering any financial benefit accrued to the defendant". 66 The court in Jansen therefore implemented this principle through a plea-bargaining and sentencing agreement coupled with an award of compensation.

On the face of it, the plea and sentencing agreements supported by compensation awards, environmental remediation or service orders have great potential to achieve environmental remediation relative to the typical impositions of low criminal fines ${ }^{67}$ and imprisonment terms that characterise normal criminal penalties. Such fines end up in the central state treasury and cannot directly be used to remedy the damage, harm or injustice caused by the accused. Environmental crimes best illustrate the benefits of allowing the prosecutor, the accused and the courts to use the consensusbased procedure that could lead to real environmental remediation. We explore below the application of this procedure to environmental crimes in South Africa. We hope to generate insights into how the South African experience can illuminate areas where the consensus-based criminal enforcement process can be refined.

\section{Plea and sentence in South African environmental criminal cases}

When an environmental crime is committed, the harm suffered is often diffuse, and sometimes there are many offenders, which makes it difficult to attribute the criminal conduct to any specific individual or corporation. This would be so in cases of non-point source water and air pollution, the

65 Jansen $v$ The State 2015 ZASCA 151 (2 October 2015).

66 Abbot 2005 JEL 172.

67 Abbot 2005 JEL 170. Such fines often have insignificant deterrence effect. For a history and evaluation of criminal sanctions in environmental law in the United States see McMurry and Ramsey 1986 Loy LA L Rev 1133-1169. 
dumping of waste, or mobile vehicular emissions, among others. ${ }^{68}$ Furthermore, the "environment" as the object of criminal conduct may be difficult to identify, which makes it difficult to identify the complainant, resulting in the state's shouldering the burden- as the custodian of the environment. ${ }^{69}$ There are obvious exceptions where the conduct in question has caused harm or damage to specific individuals or an environment on which identifiable individuals rely to sustain their livelihoods.

The potential attractiveness of the plea and sentence agreement procedure in environmental criminal enforcement is magnified when one considers the question of corporate offenders. The enforcement of environmental crimes against companies is notoriously complicated by the company being a legal fiction. ${ }^{70}$ Neither can it be imprisoned, nor can the directors, who are merely agents of the company be imprisoned - unless the law creates an exception. This leaves financial penalties as the most viable sanction against companies. ${ }^{71}$ This has been quite ineffective, given that companies often have the funds to pay financial penalties and budget for such eventualities. ${ }^{72}$ The justice of imprisoning company representatives for the crimes of the company is also constitutionally questionable, ${ }^{73}$ although it is provided for in South African environmental, ${ }^{74}$ corporate ${ }^{75}$ and criminal procedure legislation. ${ }^{76}$ In $S \vee$ Coetzee the court highlighted the rationale for corporate criminal liability and held that:

Directors, of course, occupy a special position of responsibility, not only in relation to the corporate body but also with regard to the public in general. The State consequently has an important interest in ensuring that the affairs of corporate bodies are properly and honestly conducted. The corporate body

$68 \quad$ Non-point pollution includes run-off from agricultural lands, or the pollution of a body of water by a municipality. It is difficult to attribute criminal liability to the many farmers involved.

69 The state as custodian or trustee of the environment.

70 In Minister of Water Affairs and Forestry v Stilfontein Gold Mining Co Ltd 2006 (5) SA $333(\mathrm{~W})$ para 16, the directors went to the extent of resigning en masse to avoid legal liability for water pollution caused by their mining company.

71 See s 332 of the Criminal Procedure Act.

72 Fisse and Braithwaite Corporations, Crime and Accountability 1-2, 9-10 (giving examples where corporations walked away from offences by paying their way out). $S$ v Coetzee 19971 SACR 379 (CC). Also see Woodka 1992 Tulane Envtl LJ 635, 654-60 (noting the pitfalls of the corporate liability regime in the USA).

74 Section 34(5)-(9) read with s 49A and Schedule 3 of the NEMA imposes vicarious criminal liability on companies or employers for certain actions of directors, employees or servants where the environmental offence can be attributed to their conduct. This is limited to Schedule 3 offences and not every environmental offence. The offences include water pollution, under the National Water Act 36 of 1998 (the National Water Act), s 151.

75 Companies Act 71 of 2008.

76 Section 332(5) of the Criminal Procedure Act; Snyman Criminal Law 246-247. 
itself has to be protected against the dishonesty and other criminal conduct of those in charge of its affairs or who are involved with them. It would not in itself be unreasonable to provide special measures to enable the prosecution to overcome the difficulty of gathering evidence about corporate activities. This would be consistent with the State's duty to protect society. ${ }^{77}$

The crux of plea and sentence agreements is that the state and the accused negotiate a guilty plea where the accused person admits to certain charges in exchange for the possible imposition of a reduced sentence. ${ }^{78}$ This process gives the state better powers to obtain remediation or compensation orders from the accused, which the state would otherwise not secure through normal sentencing processes.

\subsection{Connecting general provisions in section 105A Criminal Procedure Act to environmental crimes}

South Africa has been promoting industrialisation through development activities aimed at growing the economy and creating jobs to alleviate poverty. These development activities are heavily anchored in the country's mining and other energy intensive industries such as the iron and steel industry, manufacturing and agricultural processing. Most of the cases reviewed in this paper concern mining or extractive activities, which are the hotspots for environmental crimes in South Africa. This is not to discount the urgency of other environmental crimes like rhinoceros poaching. The impact of mining activities on the environment is well documented. ${ }^{79}$

Mining activities cause environmental damage in various ways, including the degradation of land, the disturbance of ecosystems, and water ${ }^{80}$ and air pollution. ${ }^{81}$ Mining can also destabilise the social fabric and livelihoods of the surrounding communities. ${ }^{82}$ In response to the deleterious effects that mining and other activities not necessarily related to mining have on the environment, the legislature enacted various pieces of legislation to regulate

$77 \quad S \vee$ Coetzee 19971 SACR 379 (CC) para 48; For an extended analysis of the implications of this case on the development of corporate criminal liability see Farisani 2017 Fundamina 1, 8-13 (where the author discusses the complexities of proving the elements of criminal liability against a director. This is very relevant to environmental crimes, where oftentimes the men rea is lacking or difficult to prove hence the overreliance on strict liability in many environmental statutes).

78 See Watney 2006 TSAR 224.

79 See generally Bell and Donnelly Mining and its Impact on the Environment; Ochieng, Seanego and Nkwonta 2010 Sci Res Essays, cf Bridge 2004 Annu Rev Environ Resour. McCarthy 2011 S Afr J Sci 3-4; Ochieng, Seanego and Nkwonta 2010 Sci Res Essays 3353.

$81 \quad$ Bridge 2004 Annu Rev Environ Resour 211, 213.

82 Petrova and Marinova 2013 Rural Society 159-160; Cronjé and Chenga 2009 Dev South Afr 414. 
such activities that have a detrimental effect on the environment. ${ }^{83}$ In recent years, however, the violation of environmental and mining legislation has reached worrying levels. This is evident from the number of criminal convictions achieved in South African courts in respect of violations of environmental regulations, as reported in the National Environmental Compliance and Enforcement Reports. ${ }^{84}$ We review a sample of these cases in the next section.

\subsection{Plea and sentencing agreements before the courts}

In S v Anker Coal \& Mineral Holdings S.A. (Pty) $L t d,{ }^{85}$ the plea and sentence agreement arose after the accused contravened the $\mathrm{NEMA}^{86}$ and the MPRDA. ${ }^{87}$ The accused company conducted prospecting activities on a wetland by drilling prospecting holes in a sensitive area. The company then failed to rehabilitate all the boreholes that had been left unsealed ${ }^{88}$ in the time period stated in a compliance notice ${ }^{89}$ issued by the regulators. The company also furnished the Department of Mineral Resources with incorrect information. ${ }^{90}$ The accused company was sentenced to a total fine of ZAR180 000 (which was suspended for five years) on three of the charges; and secondly, it was ordered to pay the sum of ZAR80 000 to Mpumalanga

83 See the NEMA, the MPRDA and the National Water Act, among others.

84 Annual reports of the Environmental Management Inspectorate (EMIs) National Environmental Compliance and Enforcement Reports show variation from year to year of criminal convictions and cases concluded. These reports are available at https://www.environment.gov.za/projectsprogrammes/emi. The 2009/10 Report states that "There has been a significant increase in the number of plea bargains from the 4 in 2008/9 to 134 in 2009/10". This is a significant increase in the number of accused persons seeking plea settlements. Then the 2012/13 Report notes that, "There has been a $7.69 \%$ (14) increase in the number of plea and sentence agreements reached in 2012/13, compared to the 13 reported in 2011/12". The 2013/14 Report records that "There has been a decrease in the number of plea and sentence agreements reached from 14 in 2012/13 to 11 reported in 2013/14". These statistics show that the use of the plea and sentence agreement procedure peaked in 2009-2010 and slowly receded in 2013-2014. $S \vee$ Anker Coal and Mineral Holdings SA (Pty) Ltd (Ermelo Regional Court) (unreported) case number ESH 8/11 (undated) (Anker Coal).

Section 28(14)(a) of the NEMA was repealed in 2013, and the essence of the section is now captured in $S 49 \mathrm{~A}(1)(\mathrm{e})-(\mathrm{g})$, which provides that "(1) A person is guilty of an offence if that person- (e) unlawfully and intentionally or negligently commits any act or omission which causes significant pollution or degradation of the environment or is likely to cause significant pollution or degradation of the environment; (f) unlawfully and intentionally or negligently commit[s] any act or omission which detrimentally affects or is likely to detrimentally affect the environment; $(\mathrm{g})$ fails to comply with a directive issued in terms of this Act". Sections 98(a)(iv) and 98(b) of the MPRDA.

88 Section 93(1)(B)(1) MPRDA.

89 Issued in terms of $s$ 93(1)(B) of the MPRDA.

90

Contravening s $98(\mathrm{~b})$ read with ss $1,99(1)(\mathrm{g})$, and 108 of the MPRDA. 
Tourism Parks Agency to empower its mandate, and lastly ZAR144 000 was to be paid as compensation to the owner of the farm ${ }^{91}$ on which the environmental damage had been caused.

In $S v$ Golfview Mining (Pty) $L t d,{ }^{92}$ the accused company contravened the NEMA ${ }^{93}$ and the National Water Act. ${ }^{94}$ In particular, the accused company was charged with the offences of conducting mining operations on a wetland, diverting a watercourse without the required water use licence, failing to separate dirty and clean water at a mining site contrary to the National Water Act, failing to deposit the "run of mine coal" within opencast box-cut areas, dumping overburden stockpile rocks into a river, failing to construct the required water pollution control measures, and commencing with listed activities without the relevant environmental authorisation (EIA approval). ${ }^{95}$

On a plea and sentence agreement the accused company was convicted of the offences charged and sentenced to a fine of ZAR1 million, which was wholly suspended for a five-year period. The accused was also ordered to pay ZAR1 million to the Water Research Council, ZAR1 million to the Mpumalanga Tourism and Parks Agency, and a further ZAR1 million to the Mpumalanga Department of Economic Development, Environment and Tourism. All payments were to be made within specified time frames and the judgment was enforceable as a civil judgment by the parties in whose favour the awards were made. In addition, three professors were to compile a peer-reviewed rehabilitation report in consultation with the then Department of Water Affairs. The report was to be compiled at the cost of the company, which was also ordered to thereafter comply with the report's

91 This compensation was ordered in terms of s 300(1) of the Criminal Procedure Act (the court may award compensation where an offence causes damage to or loss of property) which provides that "Where a person is convicted by a superior court, a regional court or a magistrate's court of an offence which has caused damage to or loss of property (including money) belonging to some other person, the court in question may, upon the application of the injured person or of the prosecutor acting on the instructions of the injured person, forthwith award the injured person compensation for such damage or loss".

$92 \quad S$ v Golfview Mining (Pty) Ltd (Ermelo Regional Court) (unreported) case Number ESH 82/11 (undated) (Golfview).

93 Sections 28(14) (now 49A) and 24F(1)(a) of the NEMA. S 24F(1)(a) read with $S$ $49 \mathrm{~A}(1)(\mathrm{a})$ of the NEMA prohibits the commencement with an activity listed as requiring an environmental authorisation (granted after an environmental impact assessment (EIA)) without the necessary authorisation. Section 151(1)(a) of the National Water Act. In terms of this section undertaking a water use, as defined in $s 21$, without a water use licence is a criminal offence. the MPRDA. 
recommendations.

In Golfview the company was co-charged with three of its directors or agents against whom all charges were withdrawn (with future immunity from prosecution) as part of the plea and sentence agreement. This is a matter to which we shall revert later, regarding the potential of this procedure to be used by negligent or reckless agents of the company to escape liability. Together with this factor, the court did not record the relationship between Anker Coal (convicted earlier in the same year of similar offences) and Golfview. Golfview was a subsidiary of Anker Coal (the accused in $S v$ Anker Coal).

In $S v$ Vunene Mining (Pty) $L t d,{ }^{96}$ the accused company, charged together with two of its director or agents, contravened the NEMA and the National Water Act. ${ }^{97}$ The accused commenced with listed activities without the required environmental authorisation, mining in a wetland and polluting water resources without a water use licence. The accused company was found guilty amongst other matters of using water contrary to section 21 the National Water Act, ${ }^{98}$ commencing activities ${ }^{99}$ without an environmental authorisation from the Department of Environmental Affairs, and committing acts or omissions which were likely to affect the environment in a significant manner. The unlawful activities had taken place for five years, from 2007 to 2012. All charges were withdrawn against the director and agents of the company, and the company itself was convicted of its plea of the offences and sentenced, in terms of an agreement, to rehabilitate the damaged environment, to pay ZAR750 000.00 to the Environmental Protection Agency, to pay ZAR250 000.00 to Ermelo Animals Rescue Services, to pay ZAR1.5 million to the Inspection, Compliance and Monitoring division of the Wildlife Protection Services Office of Ermelo, and to pay ZAR500 000 to Working for Wetlands, a non-governmental organisation towards their

$96 \quad S v$ Vunene Mining (Pty) Ltd (Ermelo Regional Court) (unreported) case number 94/11/2010 (undated) (Vunene Mining).

97 Sections 28(14)(a) (now 49A) and 24F(1)(a) of NEMA and s 151(1)(a) of the National Water Act.

98 The National Water Act specifies certain water uses that cannot be undertaken without a water use licence. Thus s 21 defines water use as meaning, for instance, "(a)- taking water from a water resource; 21(b)- storing water 21 (f) -discharging waste or water containing waste into a water resource through a pipe, canal, sewer, sea outfall or other conduit".

The listed activities included the construction of facilities or infrastructure to store 250 tons or more of coal, the removal of indigenous vegetation from 3 hectares or more, and dredging, excavating, infilling, removing or moving soils exceeding 5 cubic meters from a floodplain or wetland. These activities are now listed in revised environmental authorisation regulations. 
research and planning on wetlands in South Africa. The court also ordered the company to appear back in court after five years on 7 December 2017, in order that the court might assess if there had been compliance with the sentencing agreement. ${ }^{100} \mathrm{~A}$ follow-up inquiry as to whether the company complied with its undertakings in 2017 was not responded to by the relevant prosecutors' offices or the beneficiary entities.

As in the other cases discussed above, in $S v$ Nkomati Anthracite (Pty) $L t d^{101}$ the accused was convicted for transgressing the NEMA and the National Water Act. ${ }^{102}$ The accused commenced with listed activities without the relevant environmental authorisation in terms of the NEMA, and in the process polluted water resources, thus contravening the National Water Act. After agreeing on a plea and a just sentence the accused company was sentenced to a ZAR1 million fine, which was suspended for five years. The accused company was also compelled to pay ZAR4 million to the Environmental Management Inspectorate, the enforcement arm for specified environmental management legislation in South Africa. The money was to be used by the Inspectorate for purposes of remedying environmental damage.

In a different case, an iron and steel company entered into a plea and sentence agreement for contravening provisions of the NEMA, the Criminal Procedure Act and the National Environmental Management: Waste Act. The accused company in that case, $S \vee$ UNICA Iron Steel (Pty) Ltd, ${ }^{103}$ continued with the prohibited activities despite a compliance notice issued by the Department of Environmental Affairs to cease, desist and comply. The repeated failure to comply with administrative notices demonstrates why sometimes the enforcement agencies have no option but to pursue criminal prosecution.

In S v Samancor Chrome Ltd SHL72/2012 the accused company operated a waste disposal site for about 11 years, from August 1997 to February 2005, without the necessary permit, in contravention of the Environment

100 In terms of s 297(2) of the Criminal Procedure Act, if an accused has complied with the conditions of a postponed sentence he or she shall be discharged and "such discharge shall have the effect of an acquittal, except that the conviction shall be recorded as a previous conviction" (my emphasis).

101 S v Nkomati Anthracite (Pty) Ltd (Nelspruit Regional Court) (unreported) case number SH 412/13 (undated).

102 Section $24 \mathrm{~F}(1)(\mathrm{a})$ of NEMA and s 151(1)(a) of the National Water Act.

$103 S$ v UNICA Iron Steel (Pty) Ltd (Temba, Hammanskraal) (unreported) case number $386 / 12 / 2013$ (undated). 
Conservation Act and the NEMA. ${ }^{104}$ Secondly, the company was charged for allowing dust from the bag house facility which contained chrome and hazardous substances to be disposed of within its premises by its employees and managers without a permit.

The company was charged in terms of section 332(1) of the Criminal Procedure Act, which provides for circumstances in which a company may be liable for the criminal conduct of its directors or servants. The company had also not done an environmental assessment as then required by law. ${ }^{105}$ The accused agreed to plead guilty and to be sentenced to an agreed sentence of a fine of ZAR200 000. The accused was also ordered to pay ZAR700 $000^{106}$ to the Department of Environmental Affairs to be used together with Steelpoort Primary School in liaison with the Department of Education to "develop suitable environmental initiatives for the benefit of [the school]". ${ }^{107}$ In addition, the accused agreed to and was ordered to pay ZAR1 million ${ }^{108}$ to the Environmental Management Inspectorate (EMI) for "proper execution of their duties, environmental rehabilitation and enforcement training". Lastly the accused agreed to pay ZAR100 000 to the Department of Environmental Affairs towards prosecution costs.

In $S \vee A c k e r^{109}$ the accused individual was charged with the offence of contravening the National Water Act in that a distillery operated by Whitby Distillers and Liquor Wholesalers (Pty) Ltd disposed of the spent, untreated

104 Section 20(1) read with s 29(4) of the Environment Conservation Act 73 of 1989, and s 34(3)-(4) of the NEMA (read with Schedule 3).

105 GN 1196 in GG 15832 of 8 July 1994.

106 Ordered in terms of the then s 34(3) of the NEMA, which provided that "Whenever any person is convicted of an offence under any provision listed in Schedule 3 the court convicting such person may summarily enquire into and assess the monetary value of any advantage gained or likely to be gained by such person in consequence of that offence, and. In addition to any other punishment imposed in respect of that offence, the court may order the award of damages or compensation or a fine equal to the amount so assessed" (my emphasis).

107 S v Samancor Chrome Ltd (unreported) case number SHL72/2012 (undated) 13.

108 Ordered in terms of s 297(1)(a)(i)(aa) of the Criminal Procedure Act, and s 34(1) of the NEMA which then provided that "Whenever any person is convicted of an offence under any provision listed in Sch 3 and it appears that such person has by that offence caused loss or damage to any organ of state or other person, including the cost incurred or likely to be incurred by an organ of state in rehabilitating the environment or preventing damage to the environment. The court may in the same proceedings at the written request of the Minister or other organ of state or other person concerned, and in the presence of the convicted person, inquire summarily and without pleadings into the amount of the loss or damage so caused" (emphasis added).

109 S v Acker (Hermanus Regional Court) (unreported) case number ECH 100/05 (October 2005). Interview feedback disclosed that this matter went on appeal as accused failed to fully comply with its own undertakings. 
cooling water generated from the alcohol distilling process into the Klipdrift River. Since the unlawful discharge the company had taken extensive steps to construct a new cooling system and upgrade its plant, with the result that at the time of the hearing of the case there was no more unlawful discharge of cooling water into the river. The court sentenced the accused to payment of the sum of ZAR35 000 annually for a deserving research student studying at the Chemical Engineering Department of the University of Cape Town. The student would study the distillery and focus on research that had not as yet been conducted. In addition, in terms of the sentencing agreement the accused agreed to apply for a waste management licence from the relevant Department of Water Affairs and Forestry, as well as to monitor water quality in the Klipdrift River over a three-year period. At the end of the three years, several of the terms were not complied with and the accused appealed whereupon the compliance period was extended to three years.

In $S v$ Melville ${ }^{110}$ the accused was charged with the offences of contravening provisions of the National Environmental Management Act. The accused was found guilty of commencing activities without an environmental authorisation. The accused had transformed or removed indigenous vegetation of three hectares within a critically endangered or endangered ecosystem listed in terms of the National Environmental Biodiversity Act. ${ }^{111}$ This activity was listed as an activity that could not be undertaken without an environmental impact assessment and authorisation being issued first. The accused was issued with a compliance notice which he disregarded.

The accused persisted with the activity despite being issued with further compliance notices on two more occasions, thereby contravening NEMA. ${ }^{112}$ There is an explicit statement that the fact that "the accused had on three occasions intentionally transgressed the compliance order shows a tendency of civil disobedience". ${ }^{113}$ Upon his plea of guilty, on the first count the accused was sentenced by agreement to eighteen months imprisonment wholly suspended for five years provided the accused concluded an environmental assessment and submitted a rectification application ${ }^{114}$ within six months. Secondly, the accused was ordered to commission a rehabilitation or restoration plan by an ecologist at his own cost. On the remaining three counts relating to failure to comply with compliance notices, he was ordered to pay ZAR30 000 or six months

\footnotetext{
$110 S$ v Mellvile (Kirkwood) (unreported) case number A513/09 (undated).

111 Section 52 of the National Environmental Management: Biodiversity Act 10 of 2004.

112 Section $31 \mathrm{~N}(1)$ read with s $31 \mathrm{~N}(3), 31 \mathrm{~L}(1)(4)$ and (5) of NEMA.

$113 S$ v Mellvile (Kirkwood) (unreported) case number A513/09 (undated) 8.

114 In terms of $S 24 G$ of the NEMA.
} 
imprisonment, of which ZAR10 000 or two months imprisonment were suspended for five years on condition that the accused did not committed similar offence. This appears quite lenient, given the obstinacy and deliberateness of the accused's conduct.

In the cases reviewed above relating to mining activities and the contravention of the water legislation, common mitigation and aggravating factors were considered. We discuss these mitigating circumstances across the cases, because they indicate the extent, if any, to which the courts, in accepting sentence agreements, are attaching any weight to considerations of environmental sustainability.

In $S$ v Anker Coal, S v Golfview, S v UNICA, S v Samancor and S v Vunene Mining the courts considered the following as mitigating factors. Broadly, that the accused by pleading guilty averted lengthy trials that could cost the state a lot of money, ${ }^{115}$ that the accused cooperated with the prosecuting authorities, that the plea secured convictions which the state may have struggled to secure, ${ }^{116}$ the need to deter future offenders, to demonstrate that environmental legislation applies to all persons, and that the environmental rights in section 24 of the Constitution are important.

Also in mitigation, across these mining cases, the court noted that the mining companies "contributed to the economic and social development"117 of the areas where they are undertaking mining (although in none of the cases did the court elaborate on how the polluting activity produced any social or economic benefits), that they provided employment, ${ }^{118}$ where the mineral concerned was coal the court noted that the accused contributed "to much needed production of electricity in South Africa through mining operations", ${ }^{119}$ and that the accused companies undertook to rehabilitate the affected environments thereby possibly preventing long-term damage.

115 This is despite s 34 of the NEMA, which anyway gives the court extensive powers to order cost recovery against a convicted accused, with or without a sentence agreement.

116 This is in the context of the difficulty of gathering and presenting evidence in environmental crimes.

117 Anker Coal para 7.1.2.4-6; Samancor 10; Golfview para 9.1.2.3 -5.

118 While employment statistics were presented in some of the cases, no details of the nature and types of jobs created were provided. In Golfview it is vaguely stated in mitigation that "[t]he accused provides employment to several people".

119 Golfview para 9.1.2.5; $S$ v Acker para 7.1.2.6. Two observations can be made about this mitigation factor; firstly, mines are among the biggest consumers of electricity in the country and secondly, even though the accused is assisting by providing electricity (via coal mining) to the country, they do not do so for free. The companies are rewarded handsomely for supplying coal to Eskom. This really should not strictly be looked at as a factor in mitigation. 
In some of the cases the court noted that there was no intention by the accused to offend, but mere negligence arising often from their reliance on expert consultants to guide compliance with environmental legislation. ${ }^{120}$ In the cases where wetlands were at issue, the court took into account that South Africa as a signatory of the Convention on Wetlands (RAMSAR 1975) is bound to protect wetlands. ${ }^{121}$ Whether the accused was a first offender and the seriousness of environmental offences were emphasised as mitigating and aggravating factors respectively in some of the cases.

In Vunene Mining the court particularly emphasised that:

[t]he mining industry is in fact self-regulated with the department of Mineral Resources being under staffed and- equipped to conduct enforcement and as such require strong ethical and moral standards by the mining industry to comply to the strictest sense with the approved environmental authorizations ... As stated in De-Blom-case a person working in a specific sphere of activity ought to know the law relating to that activity. ${ }^{122}$

The court in Vunene Mining also considered that "the accused profited from the monetary gain by mining and removing coal in some portions which was not approved or provided for in an environmental management programme. Those gains were thus obtained through unlawful conduct."123 In contrast, in the non-mining cases like Acker and Mellvile the court did not deal with the socio-economic contributions of the activities as mitigating factors, nor did the court discuss the employment created by the accused. This demonstrates the general tendency by the courts to regard mining and extractive activities as more economically beneficial than other land uses such as agriculture. This runs against current research, which shows that extractive activities, particularly mining, are having devastating environmental and social impacts not only in South Africa ${ }^{124}$ but in many resource-rich countries. ${ }^{125}$

While the courts in most of these settled cases displayed awareness of the

120 This was the case in Golfview 9, where the court reiterated that despite the fact that an environmental contractor had been hired to ensure compliance, the company remained responsible and accountable for the negligence of their environmental consultants.

121 For instance, in Anker Coal para 7.1.3.8, "South Africa is a signatory to the RAMSAR convention and as such bound thereto to protect our wetlands".

122 Vunene Mining para 7.1.3(12).

123 Vunene Mining para 7.1.3(15).

124 Cronje and Chenga 2009 Dev South Afr 413, 421.

125 For detailed analyses of socio-environmental impacts of mining see generally Hilson 2002 Land Use Policy 65-73; Hamann 2004 Nat Resour Forum 270-290; Helwege 2015 Extractive Industries and Society 73-84; Moomen 2017 Resources Policy 8593; Franks, Brereton and Moran 2010 IAPA 299-312. 
seriousness of environmental offences and of the importance of environmental rights, a number of factors discussed in the next section indicate an entrenched human-centred approach that overemphasises economically useful but environmentally destructive activities. This anthropocentric approach seems to have diminished the criminal reprehensibility of environmental offenders.

Be that as it may, this group of cases, taken together, is the culmination of an emerging trend towards the use of consensus-based environmental dispute resolution mechanisms embedded in the criminal justice system. Regardless of the potential pitfalls, the procedure is an innovation in environmental enforcement and regulation in South Africa. A follow-up on the sampled cases to assess whether in fact the terms of the agreements were complied with yielded mixed but largely disappointing results that are discussed below. The research also confirmed one of the persistent challenges with environmental regulation in South Africa, which is a lack of access to information. In most of the cases it was practically impossible to get feedback on whether the sentencing agreement terms had been complied with. Many of the agencies simply did not respond to the researchers' questionnaire.

\section{Evaluating the effectiveness of sentencing agreements in environmental enforcement}

The effectiveness of an environmental enforcement tool can be measured through various methods. The rate of detection, the success of prosecution, the conviction rates and environmental integrity can be indicators of the effectiveness of a criminal justice system, together with the deterrent effect of sentences imposed. However, in environmental enforcement these are insufficient as indicators of what one may term substantive effectiveness. Substantive effectiveness in this context refers to whether a tool is in fact effective in dealing with the environment problem concerned. This is akin to what, in international environmental law, Bodansky terms "problem- solving effectiveness", which "focusses on the degree to which a treaty achieves its objectives or, more generally, solves the environmental problem it addresses". ${ }^{126}$ In the domestic context, this level of evaluation considers how environmental legislation or an enforcement tool solves the environmental mischief it was meant to address. ${ }^{127}$ In most cases this is not

126 Bodansky Art and Craft of International Environmental Law 253.

127 Patterson "Incentive-based Measures" 329. In $S$ v Acker, the order resulted in improved supervision of the Klipdrift River, although the accused struggled to do the sampling, analysis and reporting correctly until they hired an external expert. 
the case, as typically demonstrated by the environmental levies and taxes that are hardly used for cleaning up the source of pollution.

Most of the criminal justice system indicators simply demonstrate how good the criminal process is, but they do not show how the environment is being protected. If we were alert to the objectives of environmental regulation articulated above, we would see effectiveness in an improved environment, the rehabilitation of damaged areas, cleaner water and air, and ecologically sustainable and healthy ecosystems. Measuring the latter can be difficult in the absence of good technology, tools, financial resources and expertise, coupled with the continuous monitoring and reporting of data. The role of environmental civil society and public interest environmental organisations is crucial to complement the meagre resources and incapacity of government enforcement agencies in developing countries.

In 2017 we undertook the task of following up with the prosecuting authorities and the government departments involved in the sampled cases. The aim was to evaluate whether the terms and conditions of the sentence agreements were complied with or enforced. Despite continued requests there was feedback on one case only, namely $S v$ Acker. The feedback received was insightful and indicative of the strengths and pitfalls of this consensual procedure to environmental enforcement. Of the eight settlement terms, five had not been fully complied with within the stipulated timeframes. While the company had applied for authorisation of the existing waste water storage dam, the outcome was not available; the research student had not been selected on time, and the monitoring of the water quality of the Klipdrift River was monitored erratically. Regarding the latter, the Department of Water and Sanitation reported that data was collected at the wrong sites, and the water samples that had been collected and analysed had not been properly reported on as agreed. ${ }^{128}$ The department had to commission its own sampling and analysis.

The accused failed to fully comply, and on the return date the court decided not to discharge the accused, but extended the compliance period for another three years. The extension was to enable the student to consult and complete the research, on the basis of which other terms depended for implementation. The feedback on the research student indicates that the accused company complied with the payment of ZAR35 000 to sponsor the student. However, this could not be confirmed with certainty in court at the

128 Empirical feedback data on file with the authors. 
expiration of the three-year period.

The cases reviewed above and the factors which the courts considered in aggravation and mitigation as well as the sentences imposed show that sentencing agreements have the potential to fulfil the overall objects of environmental regulation. In some of the cases where wetlands or water bodies were damaged or threatened, the courts made reference to the principles of environmental management in the NEMA and international environmental law treaties. ${ }^{129}$ The aspirations that inspire South African environmental law are enshrined in section 24 of the Constitution of South Africa. Overall there is a case for better monitoring and reporting on the implementation of sentence agreements to hold accused persons accountable.

However, the circumstances of each of the cases discussed above also demonstrate the potential areas of weakness of the procedure. Firstly, the requirement in South African law that the accused must be represented to negotiate a plea and sentence agreement already excludes many environmental offenders who may not be able to afford legal representation.

Secondly, a bigger potential pitfall is the lack of sufficient scientific and financial data to enable prosecutors to negotiate a fair agreement with the accused. This is the case especially with corporate offenders, who may very well have deep pockets to pay any fine or compensation ordered. It is difficult to assess whether the agreed penalties were high enough to make the companies feel the pinch without knowing the complete financial circumstances of a company. As Abbot states:

[f]rom an economic perspective, low fines are not conducive to effective deterrence and compliance because they contribute to a reduction in the expected punishment. Coupled with the cautious approach to prosecution, the deterrent effect of this enforcement tool is limited. ${ }^{130}$

Good data can also assist the offending company by ensuring that any order it agrees to does not impose disproportionate financial obligations through costly compliance orders. Cognisance should be taken of the tendency of companies to pass on any such costs of compliance to the ultimate beneficiaries of environmental law - the ordinary consumer who pays increased prices for the products or services provided by the offending

\footnotetext{
129 In Anker Coal and Vunene Mining, the court referred to s 2(4)(r) NEMA principles on the protection of sensitive and vulnerable ecosystems. 
company. ${ }^{131}$ Apart from this, it remains difficult to quantify the actual loss suffered when a wetland is destroyed or a species is lost, ${ }^{132}$ hence any pretence to estimate what an accused should pay to offset or restore a damaged part of the environment is largely guesswork.

A more detailed study is required to assess the sentence agreements against the annual turnover or profits made by the accused companies when they were sentenced. It has been argued that any financial penalty imposed on a company should consider the interests of broader society in maintaining the survival of the company. Therefore, it must be a fine that the company can afford to pay without going insolvent, which might have social repercussions. ${ }^{133}$

The third potential weakness is that using the criminal justice system to "exonerate" criminal conduct de-stigmatises environmental offences and some of the agreed service orders and rehabilitation orders could eventually launder the accused. ${ }^{134}$ The accused company appears as an environmentally conscious and pro-environment company. This requires the court to publicise that the accused is not undertaking the project or rehabilitation services voluntarily but as a result of a criminal prosecution. It is necessary to maintain and publicise the criminal blameworthiness of the accused where for instance the accused had unlawfully and repeatedly contravened the law despite receiving cease and desist orders from environmental enforcement agencies. This would be so in cases like Mellville.

In most of the cases it is evident that the court did not seriously attach criminal blameworthiness to the accused. This was evidently difficult in cases where the company was the accused and there were no readily identifiable employees or directors responsible for the conduct causing environmental violations. In cases where this connection was apparent, the

\footnotetext{
131 What Abbot 2005 JEL 171 calls the "spillover effect on 'innocent' third parties".

132 Oliver 2016 Science 220, 221 noting that "It is a tricky problem to say how much biodiversity loss is too much". Schröter and Van Oudenhoven 2016 Trends Ecol Evol 333-334. Also see generally Costanza et al "Value of the World's Ecosystem Services" 117.

133 Abbot 2005 JEL 172.

134 This is in a context where environmental crime is still looked at as an economic crime. See Mares 2010 Crit Criminol 280, who argues that even "though criminologists have been expanding our view and understanding of what crime is, and despite the fact that some environmental crimes are now considered as heinous as traditional street crimes, ecologically harmful behavior continues to be largely viewed as an economic issue".
} 
court used stronger language of disapproval. This is evident in $S v$ Samancor, for instance.

It is important to note that the plea and sentence process presupposes a punitive dialogue overseen by the court between environmental authorities and perpetrators which dialogue is, inter alia, aimed at punishing the perpetrator, rehabilitating the environment and promoting environmental awareness and compliance with environmental laws. ${ }^{135}$

There is no silver bullet enforcement mechanism. Different combinations will be required, depending on the context of each regulator. ${ }^{136}$

\section{Conclusion: The future of negotiated enforcement in South Africa}

Courts remain central and final arbiters of the punishment and penalty imposed for environmental offences. However, the resurgence of negotiated settlements culminating in plea and sentence agreements signals a shift in environmental enforcement that could lead to better outcomes for the environment. The process of plea bargaining is consultative and participatory, involving environmental agencies, prosecuting authorities, environmental civil society and others stakeholders who have a vested interest in genuinely protecting the environment. The process thus recognises that the accused in environmental cases often has an important role to play in the economy and in society, which explains the consideration of the social contribution of the accused in mitigation of sentence, particularly for companies which contribute to economic development. The South African experience with plea and sentence agreements is therefore promising in theory. In practice, the absence of concrete information regarding the implementation and compliance with the terms and conditions of sentencing agreements is one of many concerns. This indicates the need for strong law enforcement institutions that follow through on undertakings by errant companies and individuals. Our study demonstrates that there will be no problem-solving effectiveness from the plea and sentence agreement procedure until general enforcement and institutional capacity are strengthened.

To the extent that monetary compensations and remediation orders still rely

\footnotetext{
135 This is evident from the investigative process and the agreement of the sentence between the environmental authorities and the perpetrators.

$136 \quad \mathrm{Nel}$ and Wessels 2010 PELJ 54.
} 
on the financial muscle of the offender, the process remains open to manipulation by corporate offenders with deep pockets. Wherever money is involved, the temptation for corrupt behaviour to creep in cannot be ruled out. Thus, the South African process leaves the enforcement agencies potentially exposed to corruption and rent-seeking behaviour.

Procedurally, the process in South Africa for negotiating and concluding plea and sentence agreements is complicated, cumbersome and too technical for the ordinary person. Where community members are interested and affected parties, legal assistance would be necessary to enable them to meaningfully influence the terms and conditions of the agreed penalties. Perhaps this justifies the requirement that only legally represented accused persons can resort to negotiating a plea and sentence agreement.

Some of the agreements discussed in this paper have demonstrated that the levels of penalties agreed and the orders are not as heavy as expected. Related to the leniency of the penalties and remediation orders, this study also demonstrated that the plea and sentence process could destigmatise environmental crimes and lend an element of legitimacy to sacrificing environmental integrity for economic priorities. That the court and the prosecutors in most of the cases factored into account the economic contribution of the accused's activities in mitigation indicates a propensity to treat environmental crimes as less heinous than other crimes. This attitude could negatively affect the efficacy of the criminal justice system as a tool to enforce environmental laws.

Arguably, the plea and sentence process, if effectively used, may present an effective and satisfactory mechanism to police offences of noncompliance, as it foregrounds the unique ingredients of reformation, remediation and deterrence, which are difficult to find in other environment enforcement mechanisms. For instance, it is difficult to see how a perpetrator who has received numerous directives or compliance notices alerting her to her unlawful actions and calling upon him to remedy or to desist from such unlawful conduct, or a perpetrator who wilfully fails to obtain a permit or authorisation, can be reformed by anything other than a criminal sanction imbued with environmental remediation principles. The effectiveness of the plea and sentence agreement therefore lies in its ability not only to punish the perpetrator but also to make provision for the rehabilitation of the damaged environment in furtherance of environmental regulation and enforcement. 
We conclude that further empirical research is necessary to establish the efficacy of consensus-based processes to make criminal enforcement lead to real protection of the environment. Enforcement mechanisms that result in the remediation of environmental damage and rehabilitation are the better option, and it is hoped that South African experimentation with sentence agreements can influence other jurisdictions in the region that hope to make the best out of criminal penalties in environmental enforcement.

\section{Bibliography}

\section{Literature}

Abbot 2005 JEL

Abbot C "The Regulatory Enforcement of Pollution Control Laws: The Australian Experience" 2005 JEL 161-180

Bekker 1996 CILSA

Bekker PM "Plea Bargaining in the United States of America and South Africa" 1996 CILSA 168-222

Bell and Donnelly Mining and its Impact on the Environment

Bell FG and Donnelly LJ (eds) Mining and its Impact on the Environment (Taylor \& Francis London 2006)

Billiet, Blondiau and Rousseau 2014 Regul Gov

Billiet CM, Blondiau T and Rousseau S "Punishing Environmental Crimes: An Empirical Study from Lower Courts to the Court of Appeal" 2014 Regul Gov 472-496

Bodansky Art and Craft of International Environmental Law

Bodansky D The Art and Craft of International Environmental Law (Harvard University Press Cambridge Mass 2010)

Bridge 2004 Annu Rev Environ Resour

Bridge G "Contested Terrain: Mining and the Environment" 200429 Annu Rev Environ Resour 205-259

Bridgewater, Kim and Bosselmann 2014 Yb Int'l Env L

Bridgewater P, Kim RE and Bosselmann K "Ecological Integrity: A Relevant Concept for International Environmental Law in the Anthropocene?" 2014 Yb Int'l Env L 61-78 
Clarke 1999 CILSA

Clarke CT "Message in a Bottle for Unknowing Defenders: Strategic Plea Negotiations Persist in South African Criminal Courts" 1999 CILSA 141-168

Costanza et al "Value of the World's Ecosystem Services"

Costanza $R$ et al "The Value of the World's Ecosystem Services and Natural Capital" in Newell P and Timmons Roberts J (eds) The Globalization and Environment Reader (Wiley Blackwell Hoboken NJ 2016) 117-133

Cronje and Chenga 2009 Dev South Afr

Cronje $\mathrm{F}$ and Chenga CS "Sustainable Social Development in the South African Mining Sector" 2009 Dev South Afr 413-427

Du Plessis and Nel "Driving Compliance to and Enforcement of South African Legislation"

Du Plessis W and Nel JG "Driving Compliance to and Enforcement of South African Legislation by Means of a Hybrid of 'New' Environmental Governance Instruments" in Paddock L et al (eds) Compliance and Enforcement in Environmental Law: Toward More Effective Implementation (Edward Elgar Cheltenham 2011) 259-285

Farisani 2017 Fundamina

Farisani DM "Corporate Criminal Liability in South Africa: What does History Tell Us about the Reverse Onus Provision?" 2017 Fundamina 1-19

Faure "Balancing of Interests"

Faure MG "Balancing of Interests: Some Preliminary (Economic) Remarks" in Faure MG and Du Plessis W (eds) The Balancing of Interests in Environmental Law in Africa (PULP Pretoria 2011) 1-34

Faure and Du Plessis "Comparative and Concluding Remarks"

Faure MG and Du Plessis W "Comparative and Concluding Remarks" in Faure MG and Du Plessis W (eds) The Balancing of Interests in Environmental Law in Africa (PULP Pretoria 2011) 591-619

Faure et al Criminal Enforcement of Environmental Law

Faure MG et al (eds) Criminal Enforcement of Environmental Law in the European Union (Kluwer Law International The Hague 2005)

Fisse and Braithwaite Corporations, Crime and Accountability Fisse $\mathrm{B}$ and Braithwaite $\mathrm{J}$ Corporations, Crime and Accountability (Cambridge University Press Cambridge 1993) 
Franks, Brereton and Moran 2010 IAPA

Franks DM, Brereton D and Moran CJ "Managing the Cumulative Impacts of Coal Mining on Regional Communities and Environments in Australia" 2010 IAPA 299-312

Glazewski Environmental Law

Glazewski J Environmental Law in South Africa $3^{\text {rd }}$ ed (LexisNexis Butterworths Durban 2014)

Glazewski 2014 IJMCL

Glazewski J "United States v Bengis: A Victory for Wildlife Law and Lessons for International Fisheries Crime" 2014 IJMCL 173-183

Hamann 2004 Nat Resour Forum

Hamann R "Corporate Social Responsibility, Partnerships, and Institutional Change: The Case of Mining Companies in South Africa" 2004 Nat Resour Forum 278-290

Hauck and Kroece 2006 Marine Policy

Hauck M and Kroese M "Fisheries Compliance in South Africa: A Decade of Challenges and Reform 1994-2004" 2006 Marine Policy 74-83

Helwege 2015 Extractive Industries and Society

Helwege A "Challenges with Resolving Mining Conflicts in Latin America" 2015 The Extractive Industries and Society 73-84

Hilson 2002 Land Use Policy

Hilson G "An Overview of Land Use Conflicts in Mining Communities" 2002 Land Use Policy 65-73

Holder and Lee Environmental Protection, Law and Policy

Holder $\mathrm{J}$ and Lee M Environmental Protection, Law and Policy: Text and Materials (Cambridge University Press Cambridge 2007)

Isakow and Van Zyl Smit 1985 De Rebus

Isakow D and Van Zyl Smit N "Negotiated Justice and the Legal Context" 1985 De Rebus 17

Isakow, Van Zyl Smit and Isakow 1986 SAJCC

Isakow D, Van Zyl Smit N and Isakow N "The Decision on how to Plead: A Study of Plea Negotiation in Supreme Court Criminal Matters" 1986 SAJCC 3-20 
Kidd "Criminal Measures"

Kidd M "Criminal Measures" in Paterson A and Kotzé LJ (eds) Environmental Compliance and Enforcement in South Africa: Legal Perspectives (Juta Cape Town 2009) 240-265

Kruger Hiemstra's Criminal Procedure

Kruger A Hiemstra's Criminal Procedure (LexisNexis Durban 2014)

Leggett 2003 SACQ

Leggett T "The Sieve Effect: South Africa's Conviction Rates in Perspective" 2003 SACQ 11-14

\section{Mares 2010 Crit Criminol}

Mares D "Criminalizing Ecological Harm: Crimes against Carrying Capacity and the Criminalization of Eco-sinners" 2010 Crit Criminol 279-293

Martín et al 2013 Soc Justice Res

Martín AM et al "The Relationship between Moral Judgments and Causal Explanations of Everyday Environmental Crimes" 2013 Soc Justice Res 320-342

McCarthy 2011 S Afr J Sci

McCarthy TS "The Impact of Acid Mine Drainage in South Africa" 2011 S Afr J Sci 1-7

McMurry and Ramsey 1986 Loy LA L Rev

McMurry RI and Ramsey SD "Environmental Crime: The Use of Criminal Sanctions in Enforcing Environmental Laws" 1986 Loy LA L Rev1133-1169

Moomen 2017 Resources Policy

Moomen AW "Strategies for Managing Large-Scale Mining Sector Land Use Conflicts in the Global South" 2017 Resources Policy 85-93

Mueller "Essay on Environmental Criminality"

Mueller G "An Essay on Environmental Criminality" in Edwards SM, Edwards TD and Fields CB (eds) Environmental Crime and Criminality: Theoretical and Practical Issues (Routledge London 2013) ch 1

Nel and Wessels 2010 PELJ

Nel JG and Wessels JA "How to Use Voluntary, Self-regulatory and Alternative Environmental Compliance Tools: Some Lessons Learnt" 2010 PELJ 48-78 
Ochieng, Seanego and Nkwonta 2010 Sci Res Essays

Ochieng GM, Seanego ES and Nkwonta OI "Impacts of Mining on Water

Resources in South Africa: A Review" 2010 Sci Res Essays 3351-3357

Oliver 2016 Science

Oliver TH "How much Biodiversity Loss is too much?" 2016 Science 220221

Patterson "Incentive-based Measures"

Patterson A "Incentive-based Measures" in Paterson A and Kotzé LJ (eds) Environmental Compliance and Enforcement in South Africa: Legal Perspectives (Juta Cape Town 2009) 296-335

Pelser 2007 SACQ

Pelser E "How We really got it Wrong: Understanding the Failure of Crime Prevention" 2007 SACQ 1-5

Petrova and Marinova 2013 Rural Society

Petrova S and Marinova D "Social Impacts of Mining: Changes within the Local Social Landscape" 2013 Rural Society 153-165

Pimentel, Westra and Noss "Ecological Integrity"

Pimentel D, Westra L and Noss RF "Ecological Integrity and the Aims of the Global Integrity Project" in Pimentel D, Westra L and Noss RF (eds) Ecological Integrity: Integrating Environment, Conservation, and Health (Island Press Washington DC 2000) 19-43

Preston 2014 JEL

Preston BJ "Characteristics of Successful Environmental Courts and Tribunals" 2014 JEL 365-393

Pring and Pring Greening Justice

Pring GW and Pring C Greening Justice: Creating and Improving Environmental Courts and Tribunals (Access Initiative Washington DC 2009)

Pring and Pring 2009 Or Rev Int'l L

Pring GW and Pring C "Specialized Environmental Courts and Tribunals at the Confluence of Human Rights and the Environment" 2009 Or Rev Int'l L 301-329 
Robinson 2012 Pace Envtl L Rev

Robinson A "Ensuring Access to Justice through Environmental Courts" 2012 Pace Envtl L Rev 363-395

Rousseau and Blondiau 2014 Environ Policy Gov

Rousseau S and Blondiau T "Act-based versus Harm-based Sanctions for Environmental Offenders" 2014 Environ Policy Gov 439-454

Ruggiero and South 2013 Crit Criminol

Ruggiero V and South N "Green Criminology and Crimes of the Economy: Theory, Research and Praxis" 2013 Crit Criminol 359-373

Schröter and Van Oudenhoven 2016 Trends Ecol Evol

Schröter M and Van Oudenhoven AP "Ecosystem Services Go Beyond Money and Markets: Reply to Silvertown" 2016 Trends Ecol Evol 333-334

Snyman Criminal Law

Snyman CR Criminal Law $6^{\text {th }}$ ed (LexisNexis Butterworths 2015)

Strock 1990 Geo Wash L Rev

Strock JM "Environmental Criminal Enforcement Priorities for the 1990's." 1990 Geo Wash L Rev 916-937

Wang 2016 FJHSS

Wang C "A Comparative Analysis of Environmental Courts in Sweden and China" 2016 FJHSS 607-626

Watney 2006 TSAR

Watney M "Judicial Scrutiny of Plea and Sentence Agreements: Regspraak" 2006 TSAR 224-230

Wellsmith 2011 Eur J Crim Policy Res

Wellsmith M "Wildlife crime: the problems of enforcement" 2011 Eur J Crim Policy Res 125-148

White 2005 Curr Issues Crim Justice

White R "Environmental Crime in Global Context: Exploring the Theoretical and Empirical Complexities" 2005 Curr Issues Crim Justice 271-285

White 2012 Australasian Policing

White R "NGO Engagement in Environmental Law Enforcement: Critical Reflections" 2012 Australasian Policing 7-11 
White Crimes against Nature

White R Crimes against Nature: Environmental Criminology and Ecological Justice (Routledge London 2013)

White 2017 Crime Law Soc Change

White R "Reparative Justice, Environmental Crime and Penalties for the Powerful" 2017 Crime Law Soc Change 117-132

Woodka 1992 Tulane Envtl LJ

Woodka JL "Sentencing the CEO: Personal Liability of Corporate Executives for Environmental Crimes" 1992 Tulane Envtl LJ 635-66

\section{Case law}

Bengis $v$ Government of South Africa; In re: Bengis $v$ Government of South Africa 20162 All SA 459 (WCC)

Jansen $v$ The State 2015 ZASCA 151 (2 October 2015)

Minister of Water Affairs and Forestry v Stilfontein Gold Mining Co Ltd 2006 5 SA $333(\mathrm{~W})$

North Western Dense Concrete CC v DPP, Western Cape 20002 SA 78 (C)

$S v$ Acker (Hermanus Regional Court) (unreported) case number ECH 100/05 (October 2005)

$S v$ Anker Coal and Mineral Holdings SA (Pty) Ltd (Ermelo Regional Court) (unreported) case number ESH 8/11 (undated)

S v Coetzee 19971 SACR 379 (CC)

S v Esterhuizen 20051 SACR 490 (T)

$S v$ Golfview Mining (Pty) Ltd (Ermelo Regional Court) (unreported) case Number ESH 82/11 (undated)

$S$ v Mellvile (Kirkwood) (unreported) case number A513/09 (undated)

$S \vee$ Nkomati Anthracite (Pty) Ltd (Nelspruit Regional Court) (unreported) case number $\mathrm{SH} 412 / 13$ (undated)

$S$ v Samancor Chrome Ltd (unreported) case number SHL72/2012 (undated) 
S v Solomons 20052 SACR 432 (C)

$S v$ Vunene Mining (Pty) Ltd (Ermelo Regional Court) (unreported) case number 94/11/2010 (undated)

$S$ v UNICA Iron Steel (Pty) Ltd (Temba, Hammanskraal) (unreported) case number 386/12/2013 (undated)

US v Bengis No 13-2543 (2d Cir 2015)

\section{Legislation}

\section{South Africa}

Companies Act 71 of 2008

Constitution of the Republic of South Africa, 1996

Criminal Procedure Act 51 of 1977

Environment Conservation Act 73 of 1989

Mineral and Petroleum Resources Development Act 28 of 2002

National Environmental Management Act 107 of 1998

National Environmental Management: Biodiversity Act 10 of 2004

National Water Act 36 of 1998

\section{USA}

Lacey Act, 1900 (16 USC §§ 3371-3378)

\section{Government publications}

GN 1196 in GG 15832 of 8 July 1994

\section{Internet sources}

DEA EMI 2010 https://www.environment.gov.za/sites/default/ files/docs/necer2009_10report.pdf

Department of Environmental Affairs, Environmental Management Inspectorate 2010 The National Environmental Compliance and Enforcement Report 2009-10 https://www.environment.gov.za/sites/default/ files/docs/necer2009_10report.pdf accessed 12 August 2019 
DEA EMI $2014 \quad$ 2013/14https://www.environment.gov.za/other documents/reports\#compliance2013_14

Department of Environmental Affairs, Environmental Management Inspectorate 2014 The National Environmental Compliance and Enforcement Report 2013/14 https://www.environment.gov.za/other documents/reports\#compliance2013_14_accessed 12 August 2019

DEA EMI 2017 https://cer.org.za/wp-content/uploads/2016/08/NECER2016-17.pdf

Department of Environmental Affairs, Environmental Management Inspectorate 2017 The National Environmental Compliance and Enforcement Report 2016/17 https://cer.org.za/wpcontent/uploads/2016/08/NECER-2016-17.pdf accessed 12 August 2019

Kings 2017 https://mg.co.za/article/2017-05-09-environmentalists-arewinning-the-battle-for-enforcement-of-the-law Kings S 2017 Environmentalists are winning the Battle for Enforcement of the Law https://mg.co.za/article/2017-05-09-environmentalists-are-winningthe-battle-for-enforcement-of-the-law accessed 12 August 2019

\section{List of Abbreviations}

Annu Rev Environ Resour

CILSA

Crime Law Soc Change

Crit Criminol

Curr Issues Crim Justice

DEA

Dev South Afr

EIA

EMI

Environ Policy Gov

Eur J Crim Policy Res

FJHSS

Geo Wash L Rev

IAPA
Annual Review of Environmental Resources

Comparative and International Journal of Southern Africa

Crime, Law and Social Change

Critical Criminology

Current Issues in Criminal Justice

Department of Environmental Affairs

Development Southern Africa

Environmental Impact Assessment

Environmental Management Inspectorate

Environmental Policy and Governance

European Journal on Criminal Policy and Research

Fudan Journal of the Humanities and Social Sciences

George Washington Law Review

Impact Assessment and Project Appraisal 
IJMCL

IUCN

JEL

Loy LA L Rev MPRDA

Nat Resour Forum

NEMA

Or Rev Int'I L

Pace Envtl L Rev

PELJ

Regul Gov

RAMSAR 1975

S Afr J Sci

SACQ

SAJCC

Sci Res Essays

Soc Justice Res

Trends Ecol Evol

TSAR

Tulane Envtl LJ

Yb Int'l Env L
International Journal of Marine and Coastal Law

International Union for the Conservation of Nature

Journal of Environmental Law

Loyola of Los Angeles Law Review

Minerals and Petroleum Resources

Development Act

Natural Resources Forum

National Environmental Management Act

Oregon Review of International Law

Pace Environmental Law Review

Potchefstroom Electronic Law Journal

Regulation and Governance

Convention on Wetlands

South African Journal of Science

South African Crime Quarterly

South African Journal of Criminal Law and

Criminology

Scientific Research and Essays

Social Justice Research

Trends in Ecology and Evolution

Tydskrif vir die Suid-Afrikaanse Reg

Tulane Environmental Law Journal

Yearbook of International Environmental Law 